\title{
THE KESAR SAGA THROUGH LADAKHI SONGS AND DANCE
}

\begin{abstract}
The article talks about the influence that the Kesar saga had on the folk culture of Ladakh. The examples of songs and dances that have adopted the plots of the Kesar saga are considered. The features of the legendary king Kesar are analyzed, which are embodied in modern folklore.
\end{abstract}

Keywords: Ladakhi folklore, gying-glu, Spawo dance, kha-thog

Gyalam Kesar is the best-known epic throughout the Himalayan region, particularly in Ladakh. In the past, the story of Kesar was narrated in every household during the long winter nights. In between the storytelling, the narrator would sing the songs, describing the brave deeds of Kesar and his eighteen brave heroes. The listeners, particularly the youngsters, would get very excited. These songs are found in Ladakh folklore, categorized as Ging-glu or heroic songs.

Today, some of these songs drawn from the epic have occupied a place in the popular literature of Ladakh and people sing and dance to the tune of these songs accompanied with music. In certain cases, the dancers take a sword in their hands and perform the dance, waving their hands holding the swords high in the air, known as Spawo or Sword Dance. Skillful dancers can take the dance to a high pitch.

The sword is an ancient weapon which is used in the performance of a dance. In addition, one can find the sword displayed in houses as a 'protector' weapon. Besides, the sword is also found kept in the monasteries as a protective devise. According to the Buddhist belief, a sword also dispels ignorance as well as fear from one's mind. In Buddhist temples, one can see a number of gods and goddesses with swords in their hands. The best example is that of Manjushree or Jambheyang, the god of knowledge who holds a sword in the right hand and a book in the left. In the Spawo or worrier dance, quick movement of the hands with the sword produces a feeling of thrill amongst the audience. This is a dance of bravery and hence it has now taken the shape of popular folk dance, which is generally performed by enthusiastic dancers on the occasion of an archery festival. The sword dance and the narration of Kesar stories is also popular in the Muslim-dominated areas of Kargil and Turtuk in Nubra, Ladakh. Hence, the story can be described as the most popular folk stories among the people of Ladakh.

A large number of popular songs recount the life and brave deeds of famous cultural heroes and heroines. In olden times, senior members of a family used to sing these songs to their children in order to encourage them to be brave and fearless. A great number of these songs are actually taken from the Kesar or Ge-sar epics which say how Kesar succeeded in founding and expanding the kingdom of Ling-sgar, the universe, defeating many enemies, and regaining his beloved wife from the dreaded Hor. Traditionally, the Ke-sar story is narrated only in winter months, and there is a taboo on narrating it after the fields become green. This, of course, coincides with the resumption of agricultural work after the winter break. Here is a beautiful song about the birth of Kesar:

At the heaven mother grant birth to a child,

At the world below mother Gogza gave birth to a child,

Between the realm of heaven and underworld, a goddess gave birth to a child,

And suppressing all the evil spirits, Gogza gave birth to a child.

On the auspicious day, the child descended from the heaven,

To the child all the friends and relatives grant well wishing companion,

From the heaven descends three sons of gods,

Namely, Ton-ldan, Ton-yot, and a small Tondup, fair looking.

The fair boy Tondup becomes the leader of the universe,

Will become the ruler of thousands of continents,

Like a root Lama, he could save one from going down to hell,

But at the same time, he will be a butcher who starts slaughtering from early hours. (1)

One more song is reproduced here which talks about Kesar proceeding to Horyul, the country of Hor to regain his beloved wife Cho Cho Druguma who was stolen by the King Skurgyal of Horyul:

Listen O' watchman of Hor country,

O' darkish in face, listen carefully to me, 
A guest never rest till the daybreak,

And in the evening they never inform of his coming.

A person must know his intention of coming,

A horse should be a horse to be ridden,

If person does not recognize me,

I am the Pa-le, like an old vulture.

If a horse could not recognize her own master,

It could be a beast in the wild mountainside.

Thrice the teeth of mouths have come,

Still behaves in a childish way.

Thrice the horse has drank water,

Still behaves like a horse baby.

Listen the holder of bows,

Listen to me the carrier of bows,

There three thousand arrows could be shot,

There could be three thousand arrows could not be shot.

The white path-shower arrows would be flying first,

The blackish, the real killer would follow later,

But listen, if once the arrow is shot,

That would definitely hit the target. (2)

In the story of Kesar, one finds descriptions of Buddhist cosmology or universe such as the three level of world mentioned in Buddhist texts, naming Stang-la or the heaven where the gods reside, Parsam or Middle world where humans reside and finally Luyul, the world under sea where the spirits reside. Besides, references to the three continents are found, terming as gLing-sgar, a country or place which exited in the Kham province in Tibet, the country which is said to be the land of the origin of the story or the birthplace of Kesar. Here Kesar grew up in a nine-storey palace called, gLing-sgar palace. The second land found is described as the place of dreaded people. This land or the country exited in Tibet, though the location is difficult to establish. The third and the final is Horyul, the country of Hor people.

Sarat Chandra Das, the compiler of the best known and comprehensive Tibetan-English dictionary, gives the following details of the origin of Ling Kesar:

"Ge-sar of a powerful king ruling in Shensi in China, who on account of his martial velour was deified and raised to the position of the God of War. There are various accounts of him. The people of Kham in Tibet, own him for their national war-god, while the Mongolians say that Gesar was a king of Mongolia. According to some authors, he lived in the $7^{\text {th }}$ century A.D. According to the collections of heroic songs called the Gyaldrun, King Ge-sar lived in the $8^{\text {th }}$ century A.D. His origin is, however, lost in myth".

According to the story, the king of Hor named Gyalpo Skurgyal abducted the wife of Kesar named Cho Cho Druguma while Kesar was engaged in a war campaign. Kesar for some time failed to understand where she had gone. Kesar then consulted his sooth sayer Aney Kurman Gyalmo and she forecast that the queen Druguma was abducted by none other than the King of Horyul, Skurgyal. The queen gave birth to a prince and princess known as Seral and Yural. Under such circumstances, the desperate King Kesar waged a war on the country of Hor to get back his wife.

According to Ladakhi beliefs, the legendary country Hor-yul was located somewhere in the north of Ladakh plateau, which could be any place in Central Asia. Buddhist texts and later Theosophist H.P. Blavatsky visualize that the mythical kingdom Shambhala also is located in the north of India. Based on the prophases credible Russian painter and travelers Nicolas Roerich carried an expedition to Central Asia in the search of the mythical kingdom Shambhala, crossing high mountain passes and covered the deserted plateau of Ladakh in the year 1925.

According to a document on Ladakhi history, invaders from the Central Asia, on several occasions, reached Ladakh as early as the $17^{\text {th }}$ Century and created a pandemonium-like situation in the region. The invaders reached Leh, the capital town of Ladakh. The timing was the reign of King Tashi Namgail, the founder of the Namagail dynasty in the 17th Century A.D., The king made the invaders flee back after a war in which a number of Hor warriors were killed. To mark the victory over the Hor invaders, King Tashi Namgail built the Leh palace, called Tsemo khar, burring the dead bodies of the Hor warriors under the images of protector deities.

These Hor warriors could be assumed to be of the Dzhungarian race, originally a race driven away from their mainland by the Manchu kings in the 17th Century. With the passage of time, the Tsar Kings of Russia gave them asylum and allowed to stay as their subject on the ground of allegiance to their heads. Later, due 
to their disagreement with the rulers, half of them return to their original homeland while the other half were killed. Presently, one finds the offshoot of this race settled in the Kalmyk Republic of the Russian Federation.

The Kalmyks have a long history of their finally finding home land. In the process of political upheavals, parts of Kalmykia were occupied by the German army until 1943, and were granted religious freedom by permitting to open a few Buddhist temples. Likewise, during the World War II, the majority of Kalmyks were fighting in the Soviet Army against Hitler, but some Kalmyk people on the occupied territories as they were loyal to the Germans, and they were punished by Stalin and the whole Kalmyk residents were deported en masse to Siberia from their homeland around the Volga River and Caspian Sea. According to an estimate, more than 94,000 Kalmyks were deported with their belonging to Siberia. Due to severe cold, many of them perished in Siberia.

Kalmykia is comparatively a very cold and wasteland, and its people, in the past, lived on their pasture lands with hoards of animals such as cows and horses. Interestingly, in Elista, the capital city of Kalmykia, a large sacred willow tree is standing in its dignified form and the local people pay great respect and consider it a holy tree. Like the Tibetan or Ladakhi Buddhists, Kalmyks also believe that the holy tree is the dwelling place of protector gods and goddesses. Some great Chortens(Stupas ) were built all around, with prayer flags. Kalmykia is a very sparsely populated area and people domesticate animals in abundance, and, interestingly, the wolf has the status of their National Animal. Here question how far I am right to connect story of King Gesar with the Dzhungarian race people but it is a well known fact in the world's political history it is fund recorded a number of worriers who actually came from Central Asia such as our legendary king King Gesar. And in the recorded history we find Genghis Khan, a $13^{\text {th }}$ Century warrior in Central Asia who founded the great Mongol Empire and ruled over the sizeable area of the continent.

In Ladakhi folk songs, references to King Kesar and his bravery is found in abundance. One such song say:

The dream of the night
Was a wonderful dream,
The dream of the auspicious day,
A dream of hopes fulfilled.
At the nine-storey gLin-sgar palace,
I saw rising three suns.
At the nine-storey gLin-sgar palace,
I saw rising three moons.
The great Lion King of gLing,
I saw assuming the golden throne,
The warrior gLing Kesar,
I saw assuming the golden throne.
The great Queen of gLing Druguma
Assumes the turquoise throne.
The eighteen relatives of the father
Saw seated on the right row.
The forty five relatives of the mother
Saw seated on the left row.
The great father and mother
Assume the first seat of each row.
A dwarf stands up,
And prepares rows of seats.
Similarly, Balmo Tholzoms stands up,
Pours chang in the cup.
Such happiness is not possible to find in the world of gods,
Such happiness is not possible to find in the land of the (under world) Nagas. (3)

Other gying-glu or heroic songs are sung in praise of the Ladakhi kings and queens of the past, their strength and bravery, and countless good deeds. These songs bear a strong resemblance to the gJung-glu,. In present times, they are occasionally composed in honour of the leaders of the community. In these songs, the person who is being praised frequently assumes the identity of Ke-sar. The gying-glu are sung in conjunction with the New Year festival, upper class marriage ceremonies (weddings are customarily held only during the winter season), or on such occasions when the kings or the local rulers performed the dances themselves. In the latter cases, the dance performance was initiated by a special kind of dance called kha-thog-Chen-mo. Although extremely popular in Ladakh, the ordinary people were not allowed to participate in the dance 
unless it was led by a member of an upper class family (sku-drag). On these occasions, the heroic songs would normally be sung by the musician drummers in honour of their respected dancers. Again, the music of the drums would continue for hours after the completion of the song.

In his life time, Songtsen Gampo, the $33^{\text {rd }}$ king of Tibet (569-649), emerged as the greatest of the Tibetan kings ever produced. At the initial stage his dominion was confined to Lhasa and its surroundings only but soon the kingdom's wings spread to faraway places, with communities coming into sight. The king encouraged the person's skill in art and craft to stage on a new culture and civilization in his realm. Exchange of regional folklore available in the form of folk songs, folk tales took place between different Tibetan communities. Eventually, the story of Ling Gesar emerged as one of the most popular folk literature in the Tibetan world and its lively stories reached as far as Mongolia and Buriat regions of present Russian Federation. No doubt, with the passage of time, it took the shape of the most important folk literature in the surrounding countries of Tibet such as Bhutan, Ladakh and in Baltistan, a former distract of Ladakh before the independence of India in the year 1947. It is found recorded in certain writings that the story of Ling Kesar is more voluminous than the great Indian epic, Mahabharata.

\section{Bibliography}

A Collection of Ladakhi Folk Songs published by J\&K Academy of art, culture and languages, Leh-Ladakh . Page 219. Ibid page 208

A Cultural History of Ladakh by Nawang Tsering Shakspo, Centre for Research on Ladakh. Leh Year 2019. Page 202

Ladakhi Folk Song Vol. I Compiled by Tashi Rabgais and published by J\&K Academy of art, culture and languages, Leh Ladakh.

The Kingdom of Ladakh C.950-1842 A.D. Roma, 1977. 